\title{
Mapping the Spatial Accessibility of Riau's Health Facilities using QGIS
}

\author{
Seng Hansun, Putu Perdana Kusuma Wiguna, Febri Wicaksono, Muhammad Rheza, George \\ Hodge
}

\begin{abstract}
In this study, we try to map the health facilities' spatial accessibility in Riau Province, Indonesia. Access to proper health facilities is a determinant factor in a country's development. There are some problems in establishing and developing health facilities; one of them is the health facilities' accessibility during disaster hazards. Therefore, the health facilities' location will be related to common disaster hazards, such as forest wildfire and floods. We use QGIS software to help in building and analyzing the spatial accessibility with the final web application that can be used as a supporting tool for decision-makers.
\end{abstract}

Index Terms: Health facilities, flood, forest wildfire, spatial accessibility, Riau.

\section{INTRODUCTION}

One crucial element in the development of a country is the health sector. In fact, it is one of 17 Sustainable Development Goals (SDGs) [1]. Unfortunately, the World Health Organization (WHO) [2] 2016 reportshowed that there were still many countries that areleft behind in universal health coverage. So, it is undeniable many tasks and works need to be addressed by the government and related stakeholders to improve the health coverage of their own countries.

There are different definitions of the access to healthcare facilities, but as suggested by Jamtsho \& Corner [3] and Guagliardo [4] in this study, we divide it into two parts, i.e., the potential for healthcare and the realized delivery of care. Spatial Accessibility (SA) in this study is defined as the study of healthcare accessibility in terms of its spatial components. Here, we give our focus on the healthcare facilities of Riau province, Indonesia.

Riau is an Indonesia province with a total area around $96409.54 \mathrm{~km}^{2}$. There are ten Regencies and two Cities in Riau [5]. Riau has different topographies just like other regions in Sumatra island, lowlands in the East, highlands in the West, and undulating terrain in the center region. Figure 1 shows Riau province map [5].

Revised Manuscript Received on December 30, 2019.

* Correspondence Author

Seng Hansun, Informatics Department, Universitas Multimedia Nusantara, Tangerang, Indonesia

Putu Perdana Kusuma Wiguna, Center for Spatial Data Infrastructure Development, Universitas Udayana, Denpasar, Indonesia

Febri Wicaksono, Sekolah Tinggi Ilmu Statistik (STIS), Jakarta, Indonesia Muhammad Rheza, Pulse Lab Jakarta, Jakarta, Indonesia

George Hodge, Pulse Lab Jakarta,Jakarta, Indonesia

(C) The Authors. Published by Blue Eyes Intelligence Engineering and Sciences Publication (BEIESP). This is an open access article under the CC BY-NC-ND license (http://creativecommons.org/licenses/by-nc-nd/4.0/)

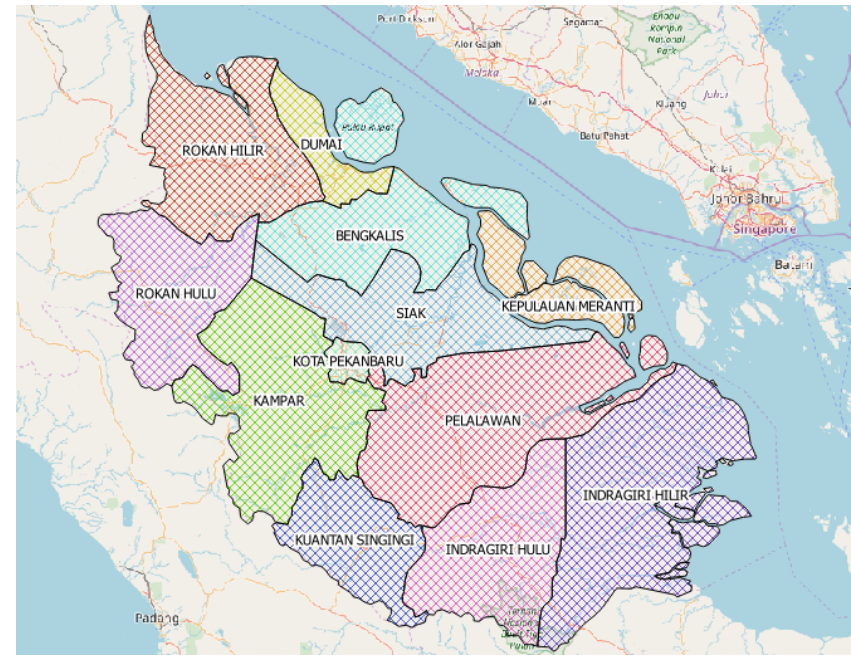

Figure 1. Riau Province Map [5]

Many have reported and studied the disaster in Riau province; however, we focus on two most common types, i.e., floods and wildfires. Nearly every year Riau experiences floods. Floods have affected at least 2,467 households and more than 10,000 individuals in 2017 [6]. Riau also has known as Indonesia's provincethat has the highest fire hotspot density,according to 2006 to 2015 data [7].

To analyze and map the disaster hazards, we incorporated Geographic Information Systems (GIS) [8], which has become an emerging technology for SA in healthcare studies [9] and become a great tool to assessthe health services distribution [10]. There is some reliable GIS software, let say the ArcGIS and QGIS. Also, there is Access Mod, a specific health-related GIS, which is developed and supported by WHO [11].

This paper is a continuation of our previous research task that has been published as a technical report of the Sixth RD by Pulse Lab Jakarta [12]. The organization of this paper is as follows. Section 2 describes the materials used in this study. The results and discussion will be given in Section 3 with the final web application built using QGIS. Finally, some concluding remarks will be given in Section 4 .

\section{MATERIALS}

The data for this study is taken from various sources of open source spatial data, as shown in Table 1. A more detail explanation of the data sources can be seen on [12].

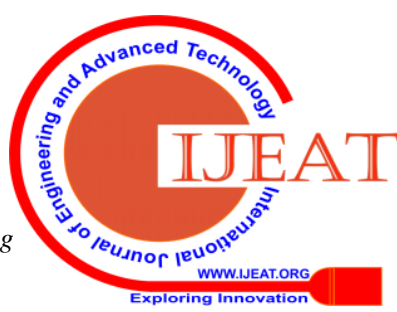




\section{Mapping the Spatial Accessibility of Riau's Health Facilities using QGIS}

\section{Table 1. Sources of Data}

\begin{tabular}{|l|l|l|}
\hline No & Data Type & Data Source \\
\hline $\mathbf{1}$ & $\begin{array}{l}\text { Riau's regency/ city } \\
\text { boundaries }\end{array}$ & $\begin{array}{l}\text { Riau Spatial Planning } \\
\text { Map }\end{array}$ \\
\hline $\mathbf{2}$ & $\begin{array}{l}\text { Riau's road map facilities } \\
\mathbf{3}\end{array}$ & $\begin{array}{l}\text { Health } \\
\text { distribution } \\
\text { Google Earth Map and }\end{array}$ \\
\hline $\mathbf{4}$ & Hotspot distribution & Haze Gazer \\
\hline $\mathbf{5}$ & Digital Elevation Model & USGS \\
\hline
\end{tabular}

Figure 2 to Figure 6 show some of the geospatial data sources.

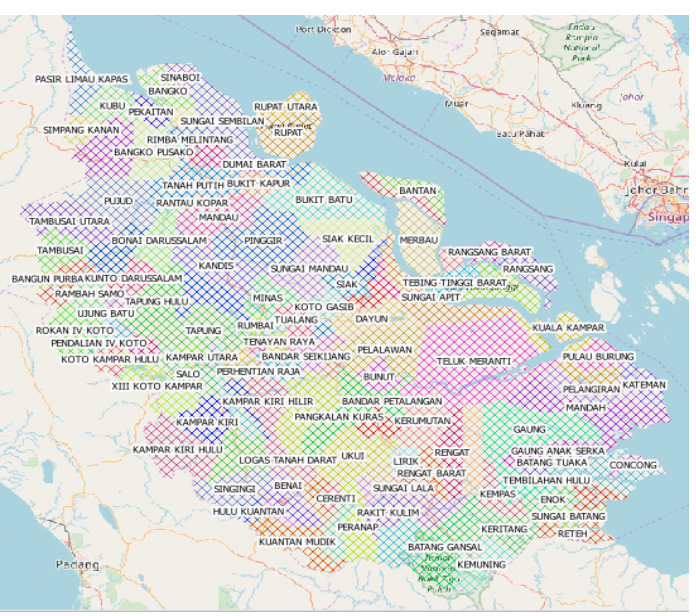

Figure 2. Riau's sub-districts

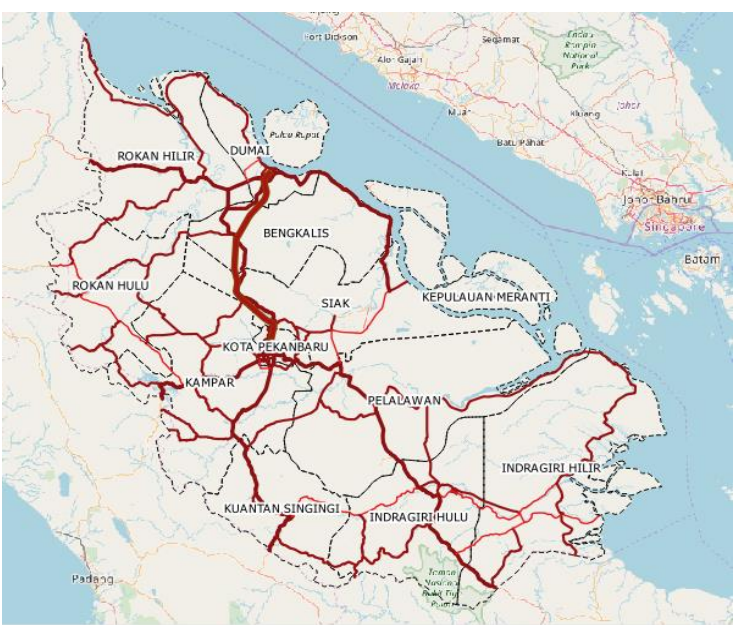

Figure 3. Riau's road network

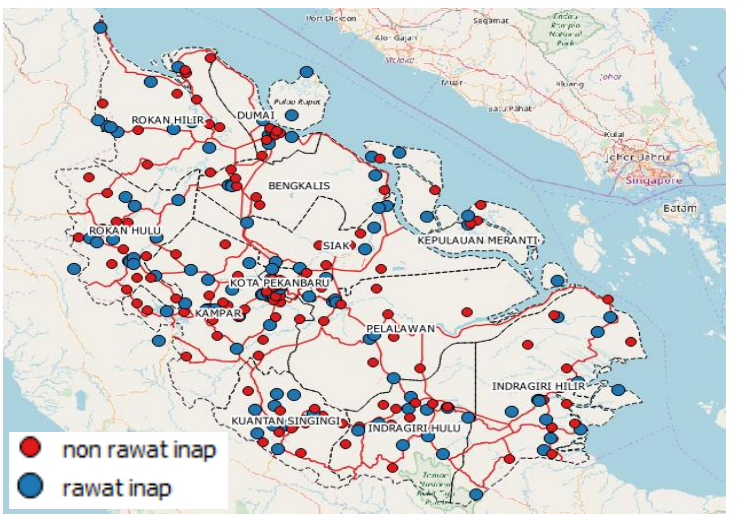

Figure 4. Riau's health facilities distribution

Retrieval Number: B3932129219/2019@BEIESP

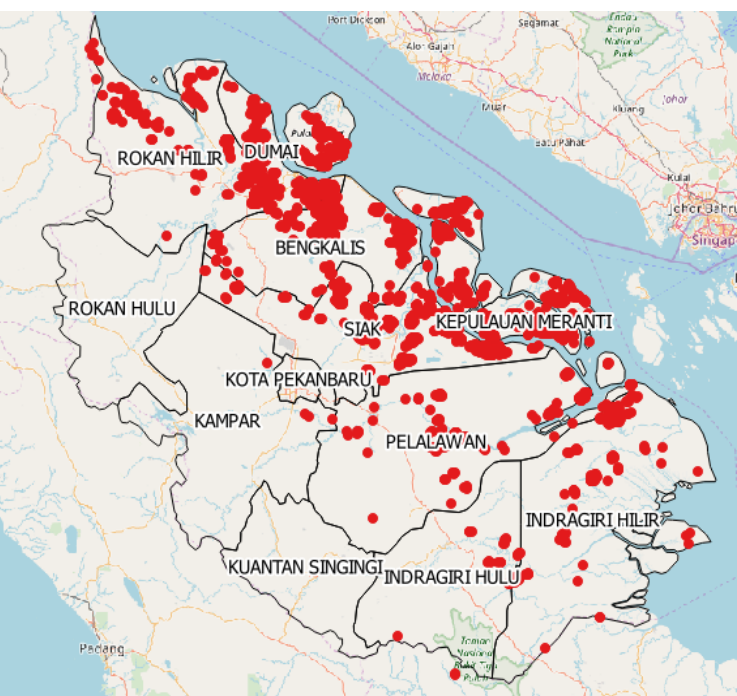

Figure 5. Riau's hotspot distribution

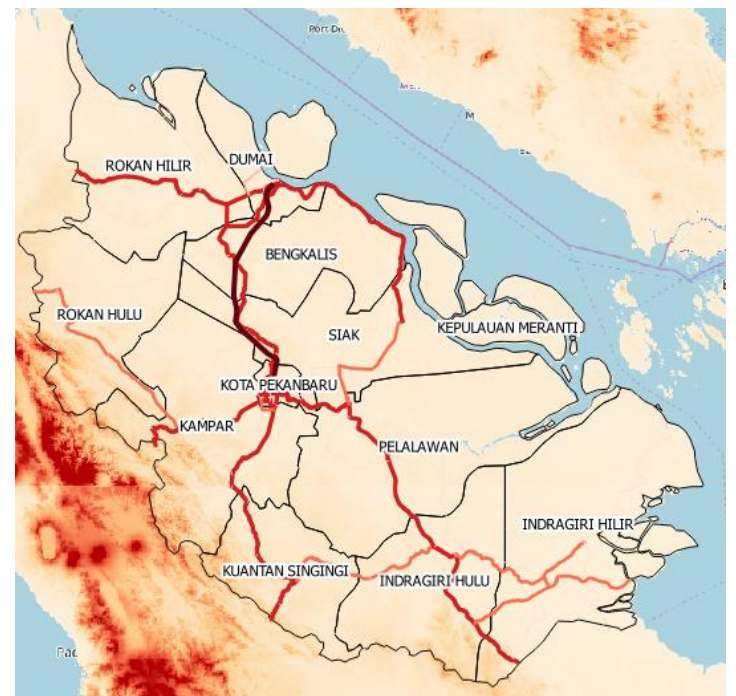

Figure 6. Digital Elevation Model map

In this study, we utilized open source GIS software, namely QGIS. It is available for download from https://www.qgis.org/en/site/ [13]. The latest testing version of QGIS is 3.10.0, but here we used 2.18.18 LTR version.

\section{RESULTS AND DISCUSSION}

First, we show the analysis results of hazards in Riau province, namely the wildfire and floods. Figures 7 and 8 show the hotspot analysis (the last recorded data was taken in 2014) and flood distribution results, respectively. From both figures we can see that most hazards are spread across inRiau's northern region, so the analysis should focus on the health facilitiesplaced outside of the hazardous region.

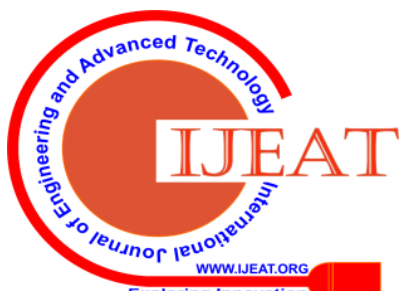




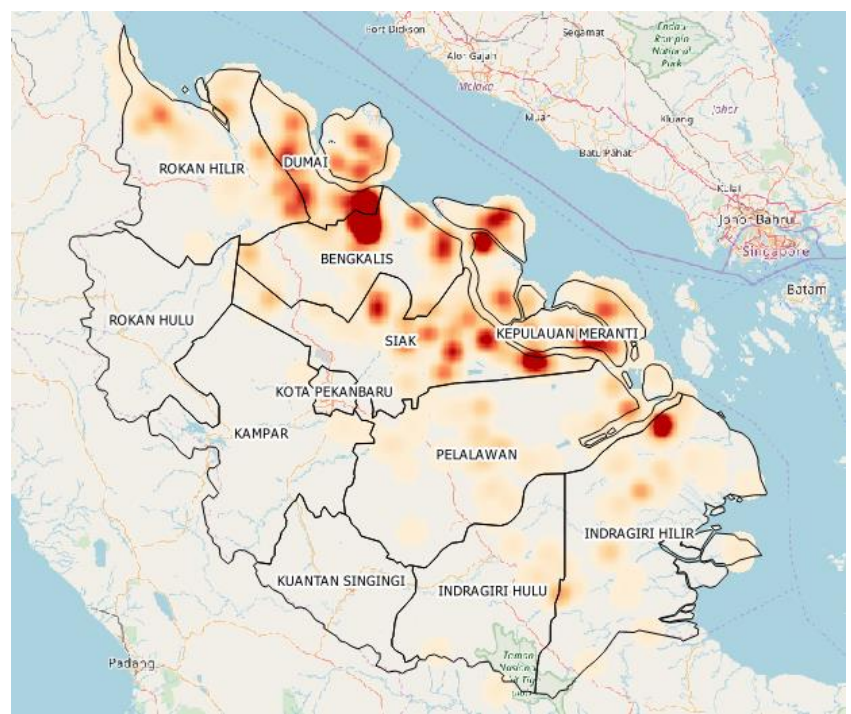

Figure 7. Hotspot Analysis Results

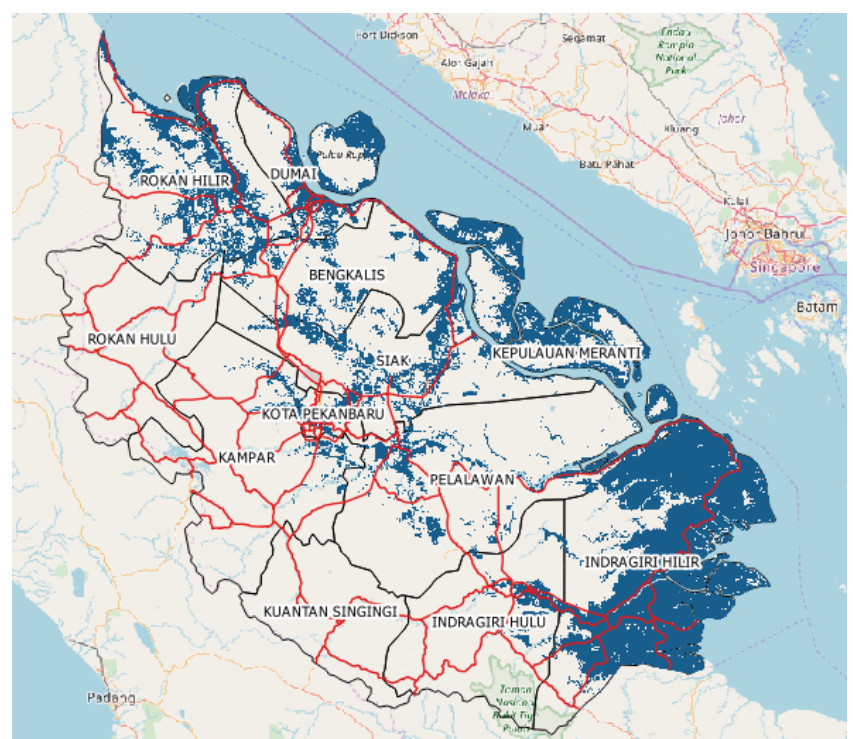

Figure 8. Flood Distribution

The next two figures show the health facilities' distance from the regency or city centers (Figure 9) and the distance from the main roads (Figure 10).

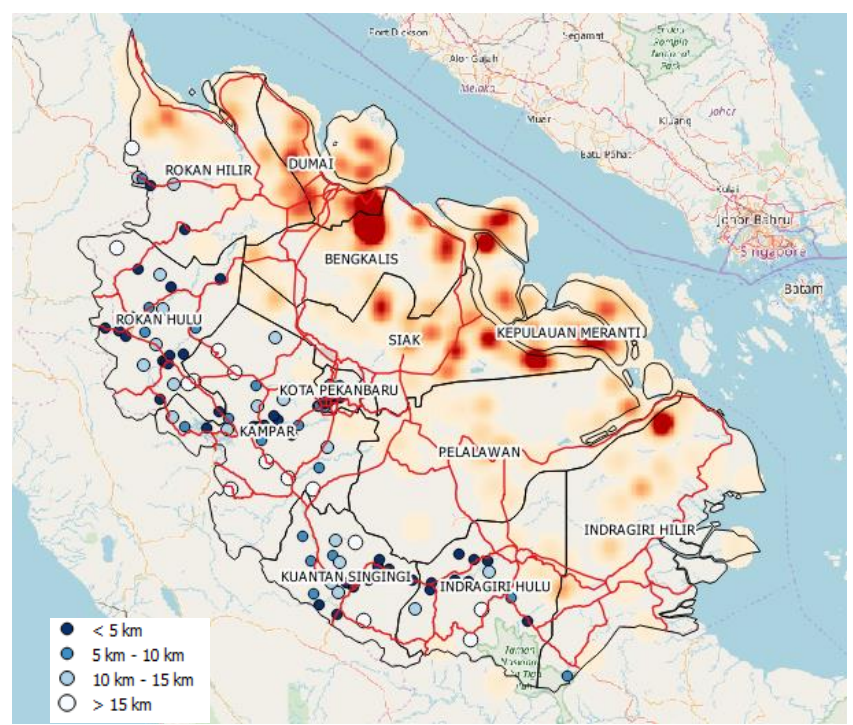

Figure 9. Health Facilities' Location from Districts' Centers

Retrieval Number: B3932129219/2019@BEIESP

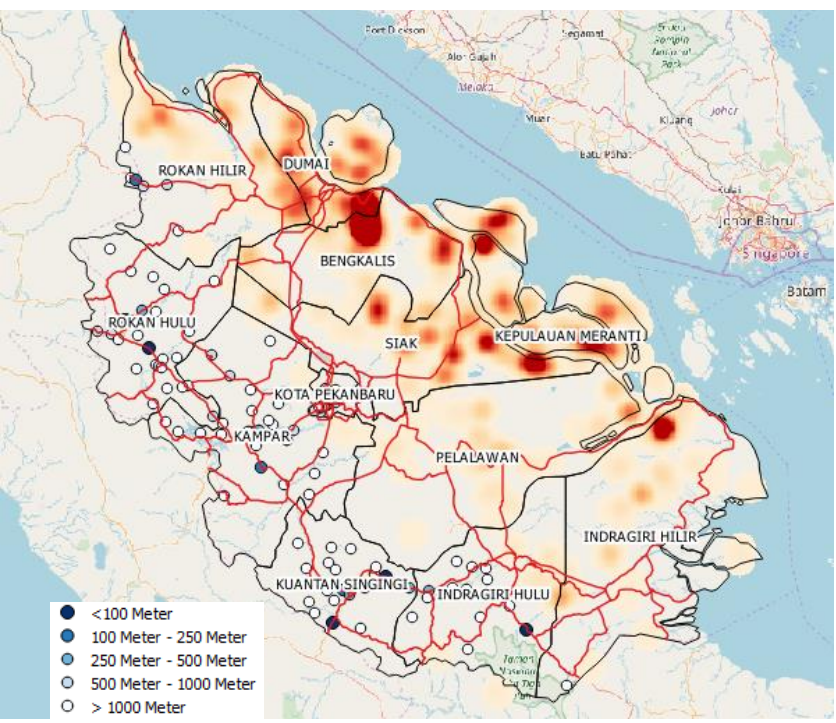

Figure 10. Health Facilities' Location from Main Roads

By using the location and distance, we could analyze and classify the health facilities' SA into five categories. Theanalysis results of health facilities'accessibility in Riau province is shown in Figure 11.

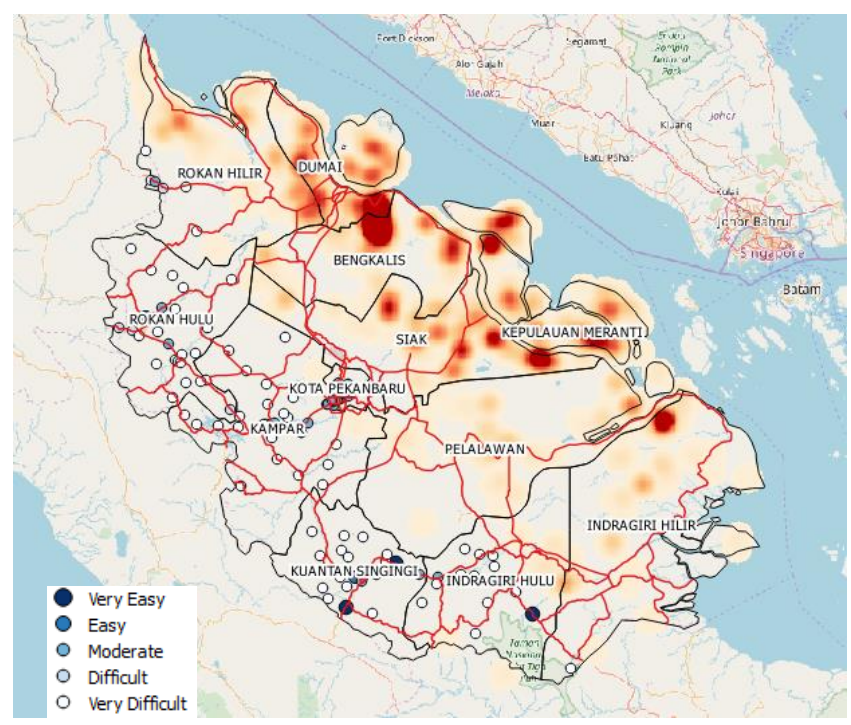

Figure 11. Accessibility of Health Facilities

Lastly, we try to build a web application that can be used to help the decision-makers in creating a policy, developing proper infrastructures, and improving the quality of health facilities regarding the disaster hazards in Riau province. Figure 12 shows the prototype result of the web application built using QGIS. 


\section{Mapping the Spatial Accessibility of Riau's Health Facilities using QGIS}

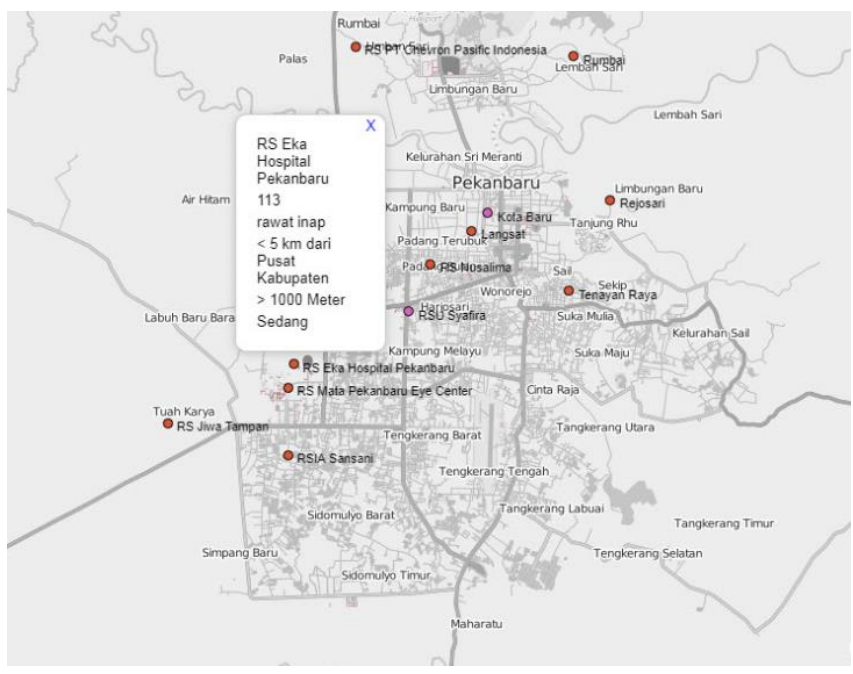

Figure 12. Web app for the health facilities' accessibility in Riau province

\section{CONCLUSION}

From the analysis results, only three health facilities in Riau provinceareclassified to have very easy access, while eight others are classified to have easy access related to hazards. The other health facilities in Riau province are still considered difficult to access related to disaster hazards. Moreover, we have successfully built a web application prototype that can help the decision-makers and communities in Riau province to take proper actions regarding the health facilities' accessibility during hazardous events. For future studies, the web application can be developed and finalized as a media to build citizen awareness of hazards and the relationship with the accessibility of Riau province health facilities.

\section{ACKNOWLEDGMENTS}

The team would like to thank the Australian Government and Pulse Lab Jakarta (PLJ) for the support givenduring the research period, especially forthe data access, facilities, and logistics.

\section{REFERENCES}

1. United Nations, Sustainable Development Goals: 17 Goals to Transform Our World. [Online] Available at http://www.un.org/sustainabledevelopment/health/.

2. United Nations, Health. [Online] Available at http://www.un.org/en/sections/issues-depth/health/.

3. S. Jamtsho and R.J. Corner, "Evaluation of spatial accessibility to primary healthcare using GIS," ISPRS Ann. Photogramm. Remote Sens. Spatial Inf. Sci, vol.II-2, pp. 79-86, 2014, https://doi.org/10.5194/isprsannals-II-2-79-2014.

4. M.F. Guagliardo, "Spatial accessibility of primary care: concepts, methods and challenges," International Journal of Health Geographics, vol.3:3, pp. 1-13, 2004.

5. BPPD, RPJMD Provinsi Riau Tahun 2014-2019, https://www.bappenas.go.id/files/rpjmd_dan_rkpd_provinsi/Riau/RPJ MD\%20Provinsi\%20Riau\%202014\%20-\%202019.pdf

6. R. Kurniawansyah, "Korban banjir Riau mencapai 10.391 jiwa,” Media Indonesia. [Online] Available at http://mediaindonesia.com/read/detail/94992-korban-banjir-riau-menca pai-10-391-jiwa.

7. I. Albar, I.N.S. Jaya, B.H. Saharjo, and B. Kuncahyo, "Spatio-temporal typology of land and forest fire in Sumatra," IJEECS, vol.4, no.1, pp. 83-90, 2016,http://doi.org/10.11591/ijeecs.v4.i1.pp83-90.

8. M.I. Prasetiyowati, "Sistem Informasi Geografis Penilaian Lokasi Alternatif untuk Penentuan Lokasi Waralaba," Proc. of Konferensi Nasional Sistem Informasi (KNSI), pp. 1409-1413, 2012.
9. L.Y. Wong, B.H. Heng, J.T.S. Cheah, and C.B. Tan, "Using spatial accessibility to identify polyclinic service gaps and volume of under-served population in Singapore using Geographic Information System," International Journal of Health Planning and Management, vol.27:3, pp.e173-e185, 2012.

10. S. Mansour, "Spatial analysis of public health facilities in Riyadh Governorate, Saudi Arabia: a GIS-based study to assess geographic variations of service provision and accessibility," Geo-spatial Information Science, vol.19:1, pp. 26-38, 2016.

11. AccessMod 5. [Online] Available at https://www.accessmod.org/.

12. P.P.K. Wiguna, F. Wicaksono, S. Hansun, M. Rheza, and G. Hodge, "Spatial Accessibility of Health Facilities in Relation to Disaster Hazards in Sumatra: Case Study in Riau Province," Technical Report, pp. 10-15, 2018, https://pulselabjakarta.org/assets/uploadworks/2018-11-06-04-24-02.p df.

13. QGIS. [Online] Available at https://www.qgis.org/en/site.

\section{AUTHORS PROFILE}

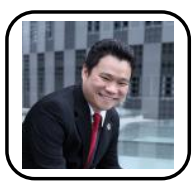

Seng Hansun, had finished his Bachelor and Master's degree from Universitas Gadjah Mada, majoring in Mathematics and Computer Science program. Since 2011, he has been a lecturer and researcher at Universitas Multimedia Nusantara and published more than 100 papers both nationally and internationally. His research interests mainly in time series analysis and machine learning domain where he has successfully granted some research grants from the government and UMN institution. 